\title{
Rumus Indeks Ketidaknyamanan Suatu Wilayah
}

\author{
Sugiasih \\ Badan Pertanahan Nasional, Jalan Brigjend Katamso (Komplek THR) Yogyakarta 55152, Indonesia
}

Korespondensi; Email: sugiasih@yahoo.com

\begin{abstract}
Abstrak
Indeks ketidaknyamanan bisa ditentukan, nilai ini untuk mengakomodasi setiap orang pada tingkat bagaimana manusia dianggap nyaman di suatu tempat. Ada tiga yang menulis rumus yaitu Indeks Ketidaknyamanan (DI), Indeks Kelembaban Suhu (THI) dan Comfort Index (CI). Selain suhu udara, kelembaban udara, kecepatan angin di sana yang mempengaruhi kenyamanan suatu tempat, seperti kepadatan bangunan, jarak ke pusat industri, jarak ke pusat perdagangan, jarak ke jalan utama, Cakupan vegetasi di daerah permukiman.
\end{abstract}

Kata Kunci: Indeks ketidaknyamanan; Indeks Kelembaban Suhu; Indeks Kenyamanan

\begin{abstract}
Index of discomfort can be determined, this value is to accommodate everyone at level how humans are considered to be comfortable on a place. There are three who wrote formulas i.e., Discomfort Index (DI), temperature Humidity Index (THI) and Comfort Index (CI). In addition to air temperature, air humidity, wind speed there that affect the comfort of a place, such as the density of buildings, distance to the center of the industry, the distance to the center of the trade, the distance to the main street, the coverage of vegetation in the area of the settlements.
\end{abstract}

Keywords: Discomfort Index; Temperatur Humidity Index; Comfort Index

\section{Pendahuluan}

Ketidaknyamanan di daerah permukiman yang dipengaruhi oleh fenomena iklim merupakan ketidaknyamanan fisiologis. Menurut Eddy Indarto (1993), ketidaknyamanan fisiologis penghuni rumah tempat tinggal mempertimbangkan dua gatra. Pertama adalah bangunan rumah tempat tinggal, kedua adalah pengaruh sengatan panas pada organ tubuh. Untuk mengkaji kedua gatra tersebut diatas memerlukan informasi yang berkaitan dengan rumah tempat tinggal, penghuni dan pengaruh sengatan panas pada organ tubuh manusia.

Untuk penentuan tingkat kenyamanan di daerah permukiman diperlukan informasi yang berkaitan dengan lingkungan permukiman dan informasi yang berpengaruh terhadap perubahan-perubahan elemen-elemen iklim seperti suhu udara, kelembaban relatif, dan kecepatan angin.

Menurut Lily Pudjiastuti, dkk (1998), tingkat panas udara memainkan peranan yang sangat penting pada persepsi tentang kenyamanan seperti halnya parameter kenyamanan yang lain. Hal ini tentu penilaian yang sangat subyektif. Udara merupakan media utama dalam mekanisme untuk panas dimana kecepatan udara dan turbulensinya berpengaruh terhadap proses pendinginan. Tingkat infiltrasi yang tinggi atau merubah kecepatan udara yang tidak penting menghasilkan hilangnya pengaturan udara dan mungkin mengurangi kondisi yang nyaman.

Beberapa faktor yang berpengaruh terhadap tingkat panas yang nyaman adalah sebagai berikut

a. Temperatur dan radiasi

Tingkat panas didominasi temperatur disekitarnya. Namun demikian standar udara kering atau temperatur ambien udara sering tidak cukup sebagai indikator untuk kriteria tingkat kenyamanan. Oleh karena itu, perlu dilakukan pendekatan yang lebih kompleks untuk menggambarkan temperatur berkaitan dengan kenyamanan.

b. Kelembaban relatif 
Pada lingkungan yang ada di dalam ruangan, sekitar $25 \%$ dari panas tubuh diemisikan oleh transpirasi. Sebagai temperatur udara ambien dan meninngkatnya aktivitas metabolisme, transpirasi yang hilang meningkat diantara 50 dan 80 persen dari total emisi tubuh. Kehilangan panas karena transpirasi ditandai dengan tingginya kelembaban relatif, jadi menghasilkan panas yang tidak nyaman. Dengan kata lain udara kering pada temperatur rendah sampai dengan normal membuat kehilangan transpirasi dan mengakibatkan dehidrasi.

c. Kecepatan udara dan turbulensi

Tingkat kenyamanan panas dipengaruhi oleh kecepatan udara dan besarnya turbulensi yang terjadi. Ketika pendinginan diperlukan, peningkatan kecepatan udara dapat dilakukan untuk mendapatkan keuntungan, sebagai contoh dengan sirkulasi udara dan kecepatan angin.

d. Pakaian

Pakaian menyediakan insulasi dan memegang peranan yang penting pada penerimaan temperatur. Pemilihan pakaian dapat menjadi alternatif untuk kenyamanan.

Menurut Eddy Indarto (1993) penelitian tentang suhu udara atas ketidaknyamanan fisiologis penghuni tempat tinggal mempertimbangkan dua gatra. Pertama adalah bangunan rumah tempat tinggal, kedua adalah pengaruh sengatan panas pada tubuh manusia. Untuk mengkaji kedua gatra tersebut diperlukan informasi sebagai berikut:

1. Rumah tinggal

2. Pengaruh panas pada tubuh manusia

3. Kelelahan kerja

4. Mekanisme terjadinya kelelahan

5. Pengukuran gejala ketidaknyamanan fisiologis

Singelton (1972) dalam Eddy Indarto (1993) mengutarakan bahwa sampai saat ini belum ada cara pengukuran ketidaknyamanan fisiologis atau psikologis yang dapat dipakai secara sempurna, tetapi beberapa ahli telah mengembangkan pendapatnya tentang beberapa parameter ketidaknyamanan fisiologis melalui pengukuran tingkat kelelahan sebagai berikut.

1. Waktu reaksi, yaitu reaksi sederhana atas rangsangan tunggal atau reaksi-reaksi yang memerlukan koordinasi.

2. Uji "finger-tapping", yaitu pengukuran kecepatan maksimal mengetuk-ketukkan jari tangan pada ukuran waktu tertentu.

3. Uji "fheker-fussion", yaitu yaitu pengukuran terhadap kecepatan berkelipnya cahaya (lampu) yang secara bertahap ditingkatkan sampai pada kecepatan tertentuyang memperlihatkan cahaya nampak berbaur sebagai cahaya yang kontinyu.

4. Uji Bourdan Wiersman, yaitu pengujian terhadap kecepatan bereaksi dan ketelitian.

5. Skala ketidaknyamanan fisiologis dari Industrial Fatigue Research Committte (IFRC).

Jhon R. Mather (1974) dalam Climatology: Fundamentals And Application, hal yang menyangkut kenyamanan manusia dicoba untuk disusun hubungan antara panas tubuh atau panas tambahan dari sumber eksternal dengan kondisi lingkungan yang dapat menerima panas dari tubuh, yang kemudian digunakan sebagai petunjuk untuk mengembangkan berbagai cara sebagai pendekatan dalam penentuan tingkat kenyamanan manusia.

\section{Pembahasan}

Indeks ketidaknyamanan yang sekarang diketahui sebagai indeks temperatur kelembaban, dikembangkan untuk memberikan kemudahan dalam mengevaluasi tingkat ketidaknyamanan dari kombinasi berbagai temperatur dan kelembaban. Pada berbagai formula indeks memberikan hasil yang sedikit berbeda. Perbedaan tersebut tidak signifikan karena hanya mencoba untuk mengidentifikasi suatu zona di mana sebagian besar penduduknya merasakan nyaman atau tidak nyaman. Kantor Cuaca Nasional Amerika Serikat menggunakan salah satu formula untuk indeks ketidaknyamanan. 
(Discomfort Index/DI):

$$
D I=0.4(T+T d)+15 \text { atau } D I-0.01 R h)(T-18)
$$

Dimana:

$T \quad$ : temperatur, ${ }^{o} F$

Td : temperatur titik embun, ${ }^{o} F$

$R h \quad$ : kelembaban relatif, \%

Hasilnya ditemukan bahwa nilai indeks 70 pada dasarnya nyaman, tetapi indeks di atas 70 , proporsi individual yang merasa tidak nyaman naik $50 \%$. Sedangkan tidak nyaman pada nilai indeks 75 dan diatas 80 sebagian besar individual-individual mengalami beberapa jenis ketidaknyamanan. Nilai 85 pada indeks ketidaknyamanan digunakan beberapa kantor pemerintah (Amerika Serikat) untuk meliburkan pekerja karena ketidaknyamanan akut yang dialami sebagian besar pekerja. Nilai ini dikembangkan dan diuji pada populasi Amerika Serikat (latitude tengah) dan tidak dapat diterapkan untuk daerah lain.

Menurut D. Murdiyarso dan Heny Suharsono (1992), iklim kota sangat menentukan kenyamanan kota, sebab secara langsung parameter iklim akan mempengaruhi aktivitas dan metabolisme manusia. Namun tidak semua parameter iklim dapat dimanfaatkan secara langsung untuk menentukan kenyamanan. Kenyamanan (comfort) merupakan istilah yang digunakan untuk menyatakan pengaruh keadaan lingkungan fisik atmosfer atau iklim terhadap manusia. Kondisi yang nyaman adalah apabila sebagian energi manusia dibebaskan untuk kerja produktif dan usaha pengaturan suhu tubuh berada pada tingkat yang minimum. Kenyamanan merupakan kondisi yang sangat bervariasi antara individu, sehingga sering bersifat subyektif. Disamping di pengaruhi oleh kondisi iklim, kenyamanan juga sangat ditentukan oleh aktivitas fisik manusia, pakaian dan makanan.

Untuk menyatakan kenyamanan secara kuantitatif biasanya digunakan "Temperatur Humidity Index" (THI) yang dirumuskan secara empiris, antara lain sebagai berikut:

$$
T H I=0.8 T+(R H \times T) / 500
$$

Dimana $\mathrm{T}$ adalah suhu udara $\left({ }^{\circ} \mathrm{C}\right)$, dan $\mathrm{RH}$ adalah kelembaban relatif (\%). Pada umumnya orang daerah tropis merasa tidak nyaman pada THI diatas 27. Cara lain untuk menyatakan kenyamanan adalah dengan Comfort Index (Ch) yang dinyatakan sebagai berikut:

$$
C I=0.7 T w+0.2 T g+0.1 T a
$$

dimana Ta dan Tw berturut-turut adalah suhu bola basah dan suhu bola kering, dan Tg adalah suhu bola kering yang diukur dengan termometer globe (semuanya dalam ${ }^{\circ} \mathrm{C}$ ). Bagi kota-kota tropis kisaran nilai $\mathrm{Cl}$ di dalam hutan kotanya adalah antara 2326 (Sham, 1986 dalam D. Murdiyarso dan Heny Suaharsono, 1992).

Pada Gambar 1 hubungan antara suhu udara, kelembaban relatif dan kecepatan angin menunjukkan bahwa daerah nyaman berkisar pada suhu dibawah $27{ }^{\circ} \mathrm{C}$ dan daerah tidak nyaman berada pada suhu antara $27{ }^{\circ} \mathrm{C}-32{ }^{\circ} \mathrm{C}$, sedangkan daerah yang termasuk sangat tidak nyaman pada suhu lebih dari $32{ }^{\circ} \mathrm{C}$. Berdasarkan hal tersebut ditentukan nilai $\mathrm{THI}$ masing- masing kriteria tingkat kenyamanan daerah permukiman pada Tabel 1.

Tabel 1 Kriteria Temperature Humidity Index (THI).

\begin{tabular}{ccc}
\hline No & Kriteria THI & Tingkat kenyamanan \\
\hline 1 & $<29$ & Nyaman \\
2 & $29-30.5$ & Tidak nyaman \\
3 & $>30.5$ & Sangat tidak nyaman \\
\hline Sumber: Heinz Frick, FX. & Bambang Suskiyanto, 1998
\end{tabular}




\section{Kepadatan Bangunan}

Kepadatan bangunan pada daerah perkotaan umumnya berkorelasi terhadap tingkat kenyamanan. Artinya semakin rapat akan semakin memperbesar penerimaan energi matahari, memperkecil evaporasi dan melemahkan gerakan angin. Proses tersebut akan menaikkan suhu di sekitarnya. Kepadatan bangunan permukiman diperoleh dengan membandingkan luas lahan yang tertutup atap bangunan permukiman dengan luas seluruh daerah permukiman, kemudian dikali $100 \%$. Tabel di bawah ini menunjukkan bahwa semakin padat daerah permukiman maka akan semakin tidak nyaman. Semakin besar harkat yang diberikan semakin besar pula pengaruhnya terhadap ketidaknyamanan.

Tabel 2 Kriteria kepadatan bangunan permukiman.

\begin{tabular}{clcc}
\hline Nomor & \multicolumn{2}{c}{ Kriteria } & Harkat \\
\hline 1 & Sangat jarang & $20 \%$ & 1 \\
2 & Jarang & $21 \%-40 \%$ & 2 \\
3 & Sedang & $41 \%-60 \%$ & 3 \\
4 & Padat & $61 \%-80 \%$ & 4 \\
5 & Sangat Padat & $>80 \%$ & 5 \\
\hline
\end{tabular}

Sumber: Sutanto, Goenadi, Totok Gunawan, 1981

\section{Jarak Terhadap Pusat Industri}

Kawasan industri dapat menimbulkan pencemaran di daerah sekitarnya. Biasanya kawasan tersebut sebagian besar tutupan lahannya berupa bangunan dengan jenis material bangunan memiliki konduktivitas termal yang tinggi sehingga pada siang hari akan panas. Selain itu transportasi yang cukup padat. Hal tersebut berpengaruh terhadap tingkat kenyamanan daerah permukiman di sekitarnya. Dengan asumsi bahwa semakin dekat suatu daerah permukiman dengan pusat industri maka semakin tidak nyaman daerah permukiman tersebut. Oleh karena itu, terlihat pada Tabel 2 pada jarak yang dekat memiliki harkat yang lebih besar dibandingkan dengan jarak yang lebih jauh.

Tabel 3 Kriteria jarak terhadap pusat industry.

\begin{tabular}{ccc}
\hline Nomor & Kriteria & Harkat \\
\hline 1 & $<500 \mathrm{~m}$ & 1 \\
2 & $500-1000 \mathrm{~m}$ & 2 \\
3 & $1001-1500 \mathrm{~m}$ & 3 \\
4 & $1501-2000 \mathrm{~m}$ & 4 \\
5 & $>2000 \mathrm{~m}$ & 5 \\
\hline Sumber: Analisis data dan survei lapangan
\end{tabular}

\section{Jarak Terhadap Pusat Perdagangan}

Pada daerah-daerah yang menjadi pusat perdagangan pada umumnya merupakan pusat aktivitas masyarakat perkotaan. Dengan kondisi fisik secara umumberupa kepadatan bangunan dan volume lalu lintas yang tinggi, sehingga di duga turut andil dalam perubahan elemen iklim bagi daerah sekitarnya.

Pada variabel jarak terhadap pusat perdagangan juga sama dengan variabel jarak terhadap pusat industri bahwa semakin dekat suatu daerah permukiman maka semakin besar nilai harkat ataupun sebaliknya. Artinya harkat yang semakin besar maka daerah permukiman tersebut semakin tidak nyaman.

Tabel 4 Kriteria jarak terhadap pusat perdagangan.

\begin{tabular}{ccc}
\hline Nomor & Kriteria & Harkat \\
\hline 1 & $<500 \mathrm{~m}$ & 1 \\
2 & $501-1000 \mathrm{~m}$ & 2 \\
3 & $1001-1500 \mathrm{~m}$ & 3 \\
4 & $1501-2000 \mathrm{~m}$ & 4 \\
5 & $>2000 \mathrm{~m}$ & 5 \\
\hline
\end{tabular}

Sumber: Analisis data dan survei lapangan 


\section{Jarak Terhadap Jalan Utama}

Penggunaan parameter ini dengan pertimbangan adanya kepadatan lalu lintas yang tinggi di jalanjalan utama. Kepadatan lalu lintas yang tinggi berarti adanya gas $\mathrm{CO}_{2}$ yang banyak. Kepadatan lalu lintas yang tinggi juga berakibat meningkatkan panas disekitarnya. Jalan utama yang dipertimbangkan biasanya adalah jalan arteri dan kolektor serta dipertimbangkan pula jalan yang sering terjadi kemacetan. Pada variabel ini ditunjukkan bahwa semakin dekat daerah permukiman dengan jalan utama maka semakin besar pengaruhnya terhadap ketidaknyamanan di daerah permukiman tersebut dan ditunjukkan dengan harkat yang lebih besar.

Tabel 5 Kriteria jarak terhadap jalan utama.

\begin{tabular}{ccc}
\hline Nomor & Kriteria & Harkat \\
\hline 1 & $<500 \mathrm{~m}$ & 5 \\
2 & $501-1000 \mathrm{~m}$ & 4 \\
3 & $1001-1500 \mathrm{~m}$ & 3 \\
4 & $1501-2000 \mathrm{~m}$ & 2 \\
5 & $>2000 \mathrm{~m}$ & 1 \\
\hline Sumber: Analisis data dan survei lapangan
\end{tabular}

\section{Liputan vegetasi di daerah permukiman}

Adalah prosentase lahan daerah permukiman yang tertutup vegetasi jenis pepohonan. Vegetasi memiliki kemampuan untuk menyimpan panas yang diterimanya dalam bentuk panas laten. Penyimpanan ini akan mengurangi jumlah panas yang terpakai dalam bentuk panas terasa (sensible heat) sehingga mampu mendinginkan daerah sekitarnya. Bobot pada parameter ini adalah 1. Pada daerah permukiman yang memiliki vegetasi lebih banyak memiliki nilai yang lebih rendah, hal ini menunjukkan bahwa daerah permukiman dengan liputan vegetasi akan semakin nyaman.

Tabel 6 Kriteria liputan vegetasi di daerah permukiman.

\begin{tabular}{clcc}
\hline Nomor & \multicolumn{2}{c}{ Kriteria } & Harkat \\
\hline 1 & Sangat sedikit & $<10 \%$ & 5 \\
2 & Sedikit & $10-24 \%$ & 4 \\
3 & Sedang & $25-39 \%$ & 3 \\
4 & Banyak & $40-54 \%$ & 2 \\
5 & Sangat banyak & $>54 \%$ & 1 \\
\hline
\end{tabular}

Sumber: Astin S, 1995

\section{Liputan vegetasi di luar daerah permukiman dalam radius $100 \mathrm{~m}$}

Vegetasi di luar daerah permukiman perlu juga di pertimbangkan, karena bagi vegetasi di dalam maupun diluar daerah permukiman memiliki pengaruh terhadap tingkat kenyamanan. Bobot pada parameter ini adalah 2.

Tabel 7 Kriteria liputan vegetasi di luar daerah permukiman dalam radius $100 \mathrm{~m}$.

\begin{tabular}{clcc}
\hline Nomor & \multicolumn{2}{c}{ Kriteria } & Harkat \\
\hline 1 & Sangat sedikit & $<10 \%$ & 5 \\
2 & Sedikit & $10 \%-24 \%$ & 4 \\
3 & Sedang & $25 \%-39 \%$ & 3 \\
4 & Banyak & $40 \%-54 \%$ & 2 \\
5 & Sangat banyak & $>54 \%$ & 1 \\
\hline
\end{tabular}

Sumber: Astin S, 1995 


\section{Skala kenyamanan}

Skala tingkat kenyamanan ditentukan dengan terlebih dahulu menentukan nilai total terendah dan tertinggi yang dapat diperoleh. Nilai total pada tiap satuan pemetaan diperoleh dengan mengalikan harkat dengan pembobot pada masing-masing parameter dan kemudian dijumlahkan seluruhnya. Penentuan interval tiap kriteria dilakukan dengan sistem kelas interval aritmatik, hasilnya merupakan selisih dalam skala tingkat kenyamanan. Rumus sistem kelas interval aritmatik adalah $A+x+$ $2 x+\ldots . .+n x=B$.

Dimana

$A \quad$ : nilai terendah

$B$ : nilai tertinggi

$n$ : jumlah kelas yang dikehendaki

$x$ : besarnya kelas interval pada kelas pertama

Selanjutnya batas 2 kelas dapat dihitung dengan rumus sebagai berikut:

$\begin{array}{llll}\text { Kelas } 1 & \mathrm{~A} & - & (\mathrm{A}+\mathrm{x}) \\ \text { Kelas } 2 & (\mathrm{~A}+\mathrm{x}) & - & (\mathrm{A}+3 \mathrm{x}) \\ \text { Kelas } 3 & (\mathrm{~A}+3 \mathrm{X}) & - & (\mathrm{A}+6 \mathrm{x})\end{array}$

Tabel 8 Skala Tingkat Kenyamanan.

\begin{tabular}{ccc}
\hline Nomor & Kriteria & Tingkat kenyamanan \\
\hline 1 & $\leq 40$ & Nyaman \\
2 & $41-72$ & Tidak nyaman \\
3 & $>72$ & Sangat Tidak nyaman \\
\hline Sumber: & Perhitungan berdasarkan sistem kelas interval aritmatik
\end{tabular}

\section{Kesimpulan}

Rumus tingkat kenyaman selama ini ada tiga, yaitu

a. Discomfort Index (DI)

$$
D I=0.4(T+T d)+15 \text { atau } D I-0.01 R h)(T-18)
$$

Dimana:

$T$ : temperatur, ${ }^{o} F$

Td : temperatur titik embun, ${ }^{o} F$

$R h$ : kelembaban relatif, \%

b. Temperatur Humidity Index (TH)

$$
T H I=0.8 T+(R H x T) / 500
$$

dimana $\mathrm{T}$ adalah suhu udara $\left({ }^{\circ} \mathrm{C}\right)$, dan $\mathrm{RH}$ adalah kelembaban relatif (\%).

c. Comfort Index (C)

$$
C I=0.7 T w+0.2 T g+0.1 T a
$$

dimana Ta dan Tw berturut-turut adalah suhu bola basah dan suhu bola kering, dan Tg adalah suhu bola kering yang diukur dengan termometer globe (semuanya dalam ${ }^{\circ} \mathrm{C}$ ). 


\section{Referensi}

[1] Indarto, Eddy, 1993, Pengaruh Suhu Udara Dan kelembaban Udara Terhadap Tingkat Ketidaknyamanan Fisiologis Penghuni Rumah tinggal Di Perumnas Banyumanik Semarang, Tesis-S2, Program Pasca Sarjana, Universitas Gadjah Mada, Yogyakarta.

[2] Mather, J.R., 1974, Climatology: Fundamentals And Aplications, McGraw-Hill: New York.

[3] Murdiyarso, D., S. Heny, 1992, Peranan Hutan Kota Dalam Pengendalian Iklim Kota, Seminar Sehari Iklim Perkotaan, Jakarta.

[4] Pudjiastuti, L., R. Septa, R.S. Happy, 1998, Kualitas Udara Dalam Ruamg, Direktorat Jenderal Pendidikan Tinggi, Departemen Pendidikan Dan Kebudayaan.

[5] Sutanto, Goenadi, G., Totok, 1981, Penggunaan Foto udara Untuk Pembuatan Peta Tata Guna Lahan Kotamadya Yogyakarta, PUSPICS, Fakultas Geografi, UGM, Yogyakarta. 